УДК 502:504:574

РАДІОБІОЛОГІЯ ТА РАДІОЕКОЛОГІЯ

https://doi.org/10.15407/jnpae2015.03.254

\author{
D. O. Bugai ${ }^{1}$, G. V. Laptev ${ }^{2}$, O. S. Skalskyy ${ }^{1}$, T. V. Lavrova ${ }^{2}$, R. Avila ${ }^{3}$ \\ ${ }^{1}$ Institute of Geological Sciences, National Academy of Sciences of Ukraine, Kyiv \\ ${ }^{2}$ Ukrainian Hydrometeorological Institute, National Academy of Sciences \\ and State Emergency Service of Ukraine, Kyiv \\ ${ }^{3}$ Facilia AB, Bromma, Sweden
}

\title{
ANALYSIS OF SPATIAL DISTRIBUTION AND INVENTORY OF RADIOACTIVITY WITHIN THE URANIUM MILL TAILINGS IMPOUNDMENT
}

Results are presented of the characterization of radioactivity inventory of Zapadnoe uranium mill tailings impoundment situated at Pridneprovsky Chemical Plant (PChP; Dneprodzerginsk, Ukraine). Analyses of radioactivity data set based on analytical studies of core material from 15 characterization boreholes allowed significantly refining waste volume and radioactivity inventory estimates. Geostatistical analyses using variogram function have established that radioactivity distribution in Zapadnoe tailings is characterized by regular spatial correlation patterns. Ordinary kriging method was applied to assess distribution of radioactivity in 3D. Results of statistical analyses suggest significant redistribution of uranium in the dissolved form in the residues (presumably due to water infiltration process). The developed structural model for radioactivity distribution is used for further risk assessment analyses. Derived radioactivity correlation scales can be used for optimization of sample collection when characterizing the PChP Site and similar contaminated sites elsewhere.

Keywords: uranium mill tailings, Pridneprovsky Chemical Plant, characterization of radioactivity inventory, geostatistical analysis.

\section{Introduction}

This article analyzes radioactivity data set for Zapadnoe uranium mill tailings impoundment situated at the Pridneprovsky Chemical Plant (PChP; Dneprodzerginsk, Ukraine). The PChP is a soviet time uranium production legacy site, which incorporates a number of uranium mill tailings impoundments, uranium ore storage sites, as well as multiple contaminated buildings and other uranium extraction infrastructure facilities (Fig. 1). Residues of uranium production with high content of radium, thorium, and other radionuclides of uranium decay series and chemotoxic substances were stored in the ravines in the immediate vicinity of uranium ore processing facilities. Contaminated facilities of the PChP site were not properly decommissioned. During recent years a number of national and international projects were undertaken aimed at characterization of radioactivity inventory, risk assessment and developing the remedial strategy for the PChP site [1, 2]. Zapadnoe tailings operated in the early period of plant functioning, from 1949 to 1954 . This uranium mill tailings impoundment is considered currently as one of priority radiological hazards at $\mathrm{PChP}$ site, as it represents a source of intensive migration of uranium to local groundwater and surface water system [3].

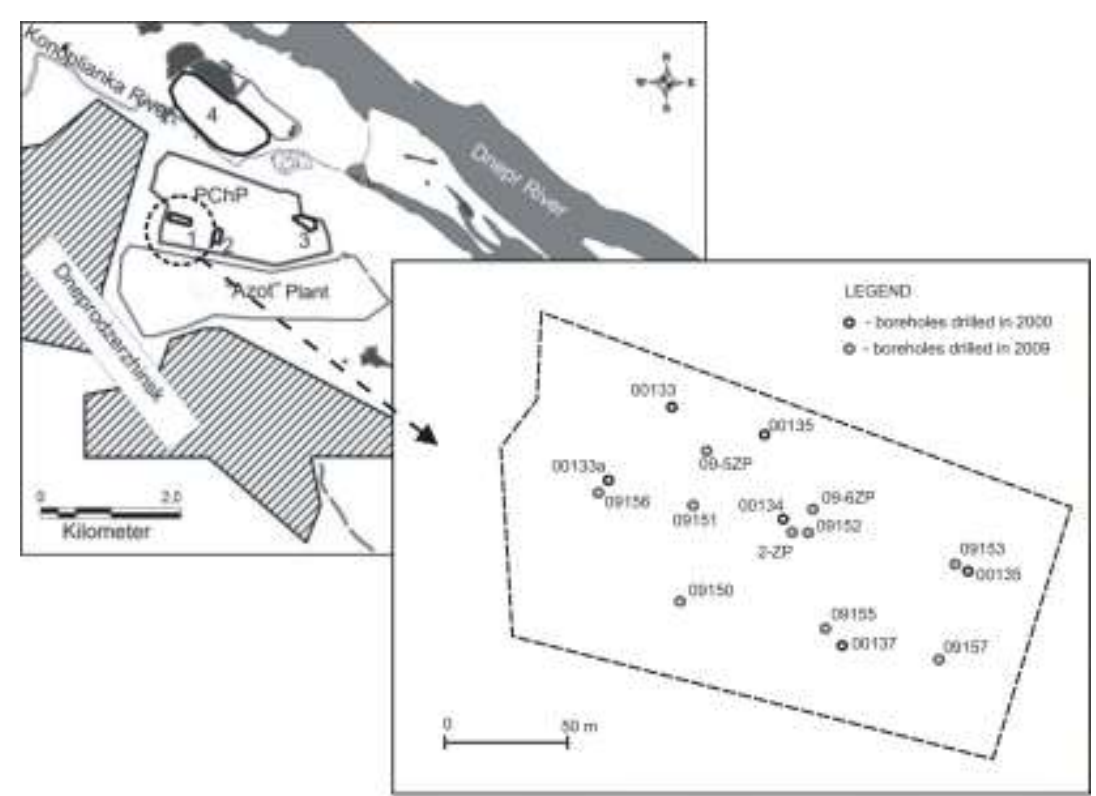

Fig. 1. Map of the PChP site and layout of characterization boreholes at Zapadnoe tailings. Numbering of uranium mill tailings at PChP site: 1 - Zapadnoe; 2 - Centralny Yar; 3 - Yugo-Vostochnoe; 4 - Dneprovskoe. 
The objective of this article is to estimate radioactivity inventory and to analyze spatial patterns of radioactivity distribution in the body of Zapadnoe uranium mill tailings impoundment in order to develop a 3D structural model for distribution of radioactivity characteristics (such as gamma- exposure rate, uranium and progeny radionuclides content) in the waste site. This was an important step for modeling uranium mill tailings as a radioactivity sourceterm for groundwater contamination, radon emission and other radionuclide transport pathways and scenarios in the frame of safety assessment and remedial analyses [3]. Radioactivity inventory analyses are based on experimental data set obtained in the course of drilling of a characterization boreholes and subsequent analyses of the core material.

The results of the analyses provided interesting insights in radioactivity distribution patterns inside the tailings. Proposed methodology and derived geostatistical parameters can be used for optimization of sample collection and analysis of data when characterizing other uranium mill tailings at the PChP Site, or for similar contaminated sites elsewhere.

\section{Study site and experimental data set}

The area of the tailings site is $4.0 \cdot 10^{4} \mathrm{~m}^{2}$. The tailings site is located in a worked-out clay pit surrounded by soil dikes. The thickness of the tailings body varies from 1 to $12.5 \mathrm{~m}$. The pit basement and dikes have not been equipped by impermeable liners. The majority of the wastes are composed of uranium mill tailings materials, which were disposed using a hydraulic discharge method. The technological scheme used acid extraction of uranium from milled ores. The tailings were neutralized before disposal to the impoundment (using lime, ammonia and other reagents). This resulted in alkaline hydrochemical conditions ( $\mathrm{pH} \approx 8-9$ ) promoting migration of uranium in the form of carbonate complexes [4]. More detailed description of Zapadnoe tailings can be found in [3].

In the frame of National Program of remediation of the PChP site initiated by the Cabinet of Ministers of Ukraine characterization and radioactivity sources inventory works were carried out at the site in 2009. In particular, in total 9 characterization boreholes ranging in depth from 3 to $19.5 \mathrm{~m}$ were drilled at the tailings site and core material was analyzed.

Core samples from tailings were collected using auger drilling method. Gamma dose rate measurements on collected core samples were carried out with $0.5 \mathrm{~m}$ depth increment. Samples for radioactivity analyses were collected from 4-12 regularly spaced depth intervals in each borehole (the number of samples was smaller for some shallow boreholes) and also taking into account dose rate measurements (to capture possible radioactivity hotspots).

All the samples collected during drilling on Zapadnoe uranium mill tailing were routinely analyzed for the radionuclide contents. ${ }^{238} \mathrm{U},{ }^{230} \mathrm{Th},{ }^{232} \mathrm{Th}$, ${ }^{226} \mathrm{Ra},{ }^{210} \mathrm{~Pb},{ }^{40} \mathrm{~K}$, and other radioisotopes were measured by direct gamma-ray spectrometry in the laboratory of gamma-ray spectrometry and radiochemistry of the Department of radiation monitoring of the environment of the Ukrainian Hydrometeorological Institute (UHMI). This laboratory is certified by UkrMetroStandard and is an active member of the IAEA network of analytical laboratories for measurement of environmental radioactivity (ALMERA).

Two types of HPGe detectors were used in this study - Low-background gamma-detector GMX40C manufactured by ORTEC (X-Ray coaxial detector with the window made of composite material) and Broad-energy gamma-detector BEGe BE5030 manufactured by Canberra. ${ }^{238} \mathrm{U}$ and ${ }^{232} \mathrm{Th}\left({ }^{228} \mathrm{Ra}\right)$ isotopes were measured on daughter short-lived radionuclides assuming that they exist in equilibrium state $-{ }^{234} \mathrm{Th}\left(63.3 \mathrm{keV}\right.$, half-life 24.1 days) and ${ }^{228} \mathrm{Ac}$ (338 keV, half-life 6.13 hours) for uranium and thorium, respectively. ${ }^{210} \mathrm{~Pb}$ and ${ }^{230} \mathrm{Th}$ were measured by direct gamma-emitting intensity lines at 46.5 and $67.7 \mathrm{keV}$ respectively, while ${ }^{226} \mathrm{Ra}$ was measured by de-convolution of total peak area at $186 \mathrm{keV}$ with accounting for partial contribution of ${ }^{235} \mathrm{U}$ into the area using calculation procedure proposed by De Cort et al. [5] as well as by estimation of daughter ${ }^{214} \mathrm{~Pb}(295$ and $352 \mathrm{keV})$ and ${ }^{214} \mathrm{Bi}(609 \mathrm{keV})$ isotopes. ${ }^{40} \mathrm{~K}$ was measured by gamma-emitting intensity line of $1460.75 \mathrm{keV}$. Efficiency of the detector was calibrated following on the results of measurements of certified reference materials (CRM - homogenized materials of soils and ores manufactured by NIST, IAEA and NPL UK where radioisotope contents are known) for various mass values and filling depth of containers. A correction was made on the self-absorption effect of low energy gammaquantum in sample's material of given matrix relatively to 'standard' soils according to Appleby et al. [6]. Measuring time was optimised (controlled by operator) in such a way that the statistical error in the peak of interest (for example, ${ }^{234} \mathrm{Th} 63 \mathrm{keV}$ ) in the spectra do not exceed 10-15\%. Activity of gamma-emitting radioisotopes was calculated using GammaVision 5.1 and ErlLib based (Liverpool University, UK) in-house UHMI software. No significant statistical fluctuations between either results of calculation have been observed.

The described above data set was complemented by data of characterization studies carried out in 2000 by Research and Project Institute of Industrial Technologies (Zhovti Vody), when 6 characteriza- 
tion boreholes ranging in depth from 5.5 to $19 \mathrm{~m}$ were drilled [7]. Layout of characterization boreholes used in this study is shown at Fig. 1. Results of 2009 studies combined with previous data produced a detailed radioactivity data set with a level of spa- tial resolution, which is a rarely available for similar contaminated legacy sites (Fig. 2). This created preconditions for application in this article of statistical and geostatistical techniques and methods for data analysis and interpretation.

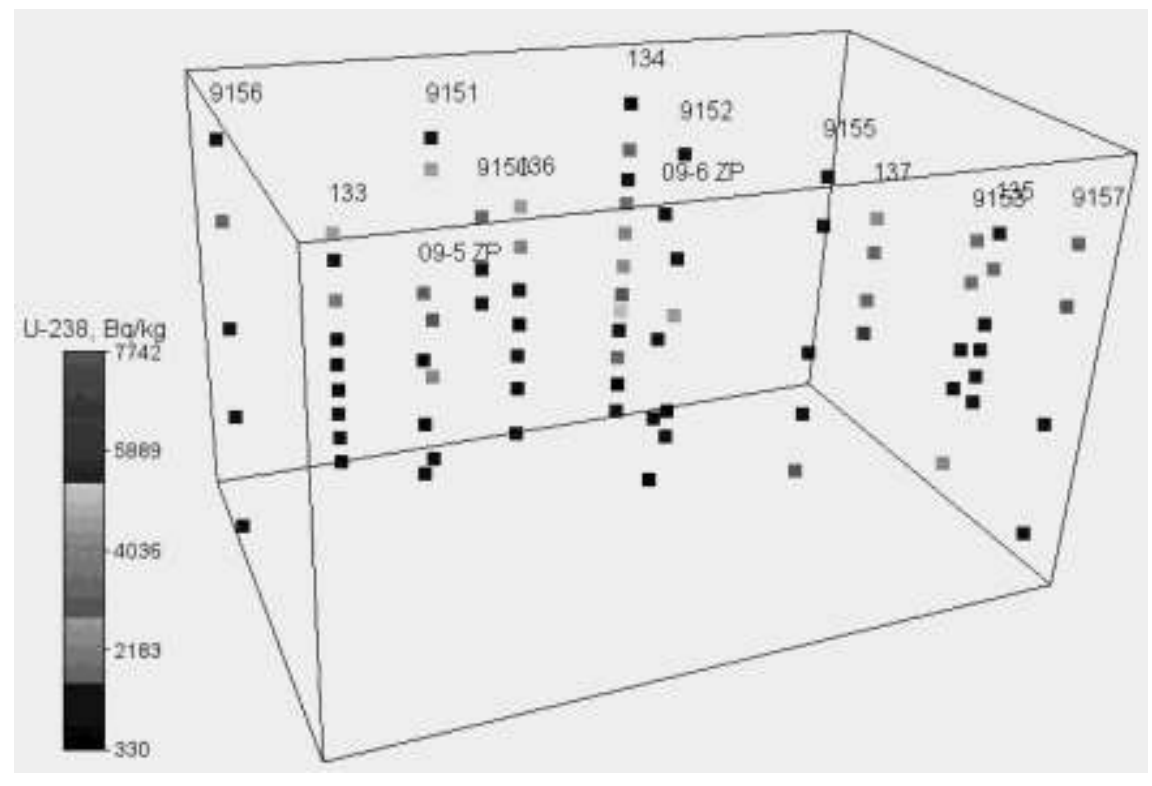

Fig. 2. Visualization of the of the analyzed uranium activity measurement data set.

\section{Statistical analysis of radioactivity data set and inventory estimation}

\section{Statistical characteristics of data set}

Statistical characteristics of the radioactivity data set are presented in Table 1. Corresponding frequency histogram for the uranium-238 activity measurements in samples are shown at Fig. 3, $a$. Analysis of data shows that uranium data set (as well as other radioactivity parameters) are approximately log-normally distributed.

Statistical procedures used in the following sections of this article (such as correlation analyses and geostatistical analyses) are based on assumptions of normality of the analyzed data set $[8,9]$. Therefore we have applied logarithmic transformation to render radioactivity data approximately normally distributed (Table 2). In particular, a data set with a normal distribution is important in interpolation using kriging [10]. The logarithm transformation also ensures non-negativity of interpolated estimates of the variable of interest after back-transformation to the variable. The symmetry of logarithmically transformed data of data is indicated by proximity of mean and median values (see Table 2). The resulting frequency histogram for the uranium-238 is close to normally-distributed, as shown at Fig. 3, $b$.

Table 1. Statistical characteristics of data set and inventory estimates for Zapadnoe tailings

\begin{tabular}{|c|c|c|c|c|c|}
\hline \multirow{2}{*}{ Parameter } & \multicolumn{4}{|c|}{ Radionuclide activity, kBq/kg d.w. } & \multirow{2}{*}{$\begin{array}{c}\text { Gamma exposure } \\
\text { rate, } \mu \mathrm{R} / \text { hour }\end{array}$} \\
\hline & ${ }^{210} \mathrm{~Pb}$ & ${ }^{226} \mathrm{Ra}$ & ${ }^{230} \mathrm{Th}$ & ${ }^{238} \mathrm{U}$ & \\
\hline Number of samples & 39 & 39 & 39 & 77 & 172 \\
\hline Min value & 0.98 & 1.03 & 1.6 & 0.3 & 80 \\
\hline Max value & 16.0 & 16.2 & 34.8 & 7.7 & 3202 \\
\hline Median & 5.0 & 5.0 & 11.3 & 1.2 & 634 \\
\hline Mean & 5.8 & 5.9 & 12.7 & 1.7 & 732 \\
\hline Standard deviation & 3.6 & 3.5 & 7.8 & 1.3 & 598 \\
\hline Standard error of the mean & 0.58 & 0.56 & 1.25 & 0.15 & 45.6 \\
\hline Activity inventory, $\mathrm{TBq}$ & $2.4 \pm 0.2$ & $2.5 \pm 0.2$ & $5.3 \pm 0.5$ & $0.72 \pm 0.06$ & - \\
\hline
\end{tabular}


Table 2. Statistical characteristics of logarithm-transformed data set for Zapadnoe tailings

\begin{tabular}{|c|c|c|c|c|c|}
\hline \multirow{2}{*}{ Parameter } & \multicolumn{4}{|c|}{ Logarithm of radionuclide activity } & \multirow{2}{*}{$\begin{array}{l}\text { Logarithm of gamma } \\
\text { exposure rate }\end{array}$} \\
\hline & ${ }^{210} \mathrm{~Pb}$ & ${ }^{226} \mathrm{Ra}$ & ${ }^{230} \mathrm{Th}$ & ${ }^{238} \mathrm{U}$ & \\
\hline Min value & 6.9 & 6.9 & 7.4 & 5.8 & 4.4 \\
\hline Max value & 9.7 & 9.7 & 10.5 & 8.9 & 8.1 \\
\hline Median & 8.5 & 8.5 & 9.3 & 7.1 & 6.5 \\
\hline Mean & 8.5 & 8.5 & 9.2 & 7.2 & 6.6 \\
\hline Standard deviation & 0.6 & 0.6 & 0.8 & 0.6 & 6.4 \\
\hline
\end{tabular}

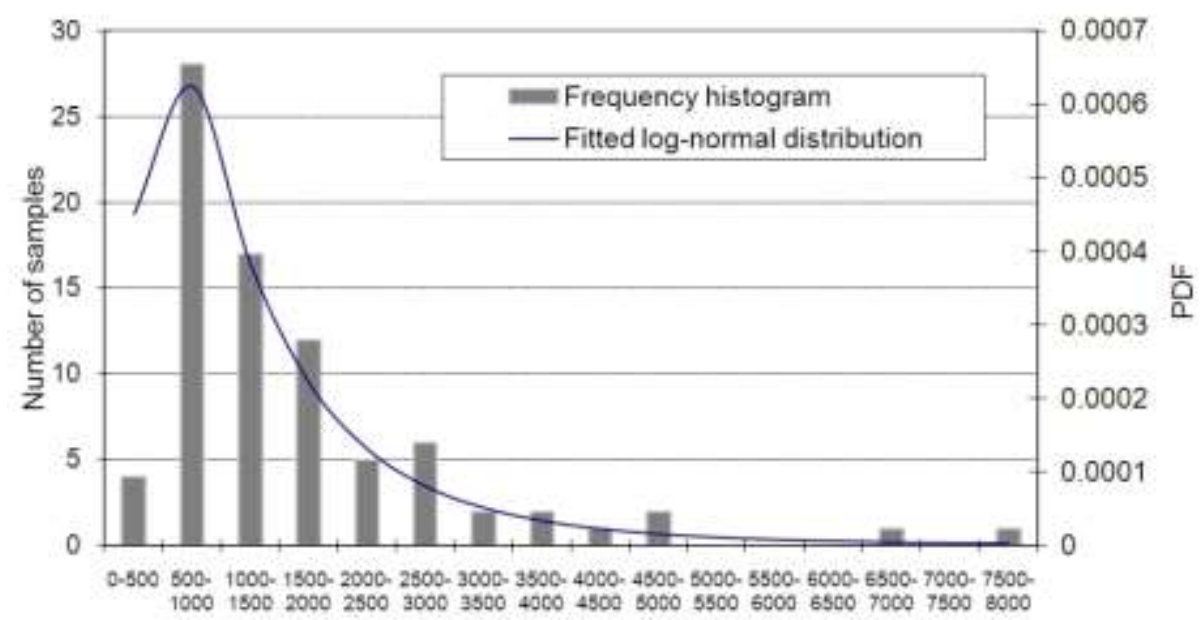

U-238, Bq/kg

$a$

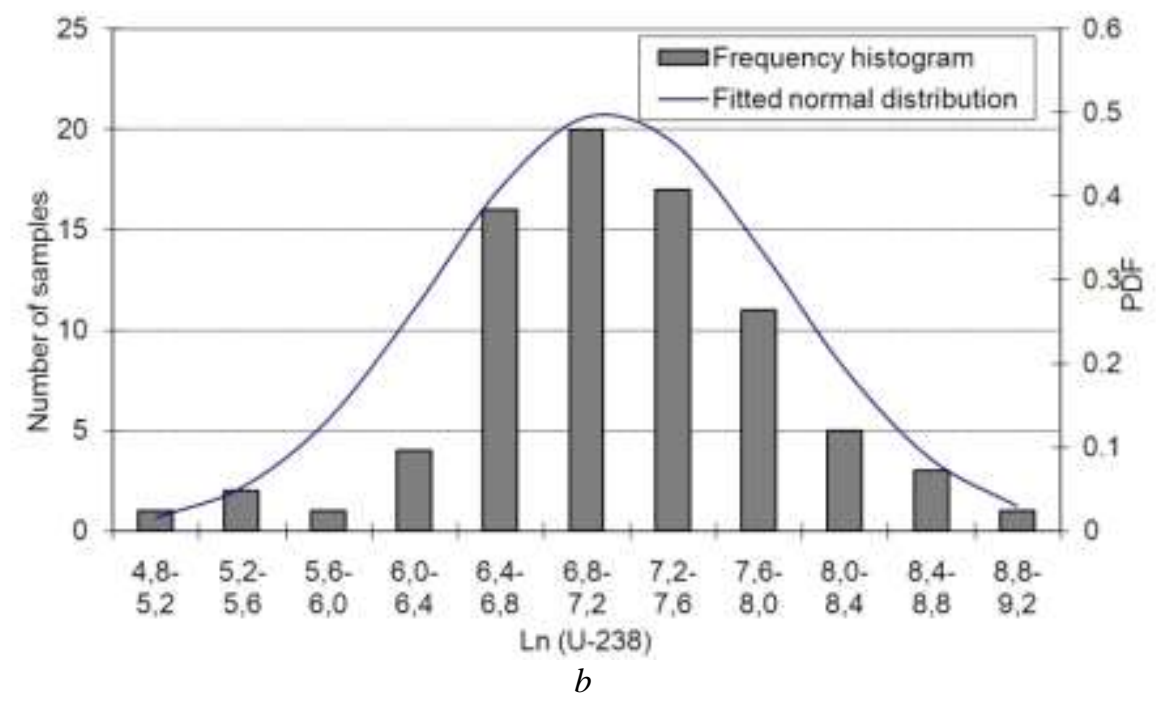

Fig. 3. Frequency histograms and fitted probability density functions for uranium-238 data set for Zapadnoe tailings: Initial data set $(a)$ and Logarithm- transformed data set $(b)$.

\section{Radioactivity inventory estimates}

Results of characterization borehole drilling were used to develop the 3D subsurface model of the geometry of soil cover and bottom of tailings impoundment. This allowed numerical estimation of the volume of waste disposed to Zapadnoe tailings at $253400 \mathrm{~m}^{3}$. This is noticeably less than the earlier approximate waste volume estimate of $350000 \mathrm{~m}^{3}$ [7].

Refined estimate of waste volume combined with statistical characteristics of radioactivity parameters allowed estimation of activity inventories of specific radionuclides in Zapadnoe tailings, which are listed in Table 1. Calculations assumed waste bulk dry density value of $\rho=1.66 \mathrm{~g} / \mathrm{cm}^{3}$.

Assuming that activity of ${ }^{234} \mathrm{U}$ equals activity of ${ }^{238} \mathrm{U}$, and that activity of ${ }^{210} \mathrm{Po}$ is in equilibrium with ${ }^{210} \mathrm{~Pb}$, the inventory of the main long-lived radionuclides in Zapadnoe tailings (that is ${ }^{238} \mathrm{U},{ }^{234} \mathrm{U},{ }^{230} \mathrm{Th}$, ${ }^{226} \mathrm{Ra},{ }^{210} \mathrm{~Pb}$ and ${ }^{210} \mathrm{Po}$ is estimated at $14.1 \pm 1.4 \mathrm{TBq}$. This value is an order of magnitude lower than the previous activity inventory estimate for Zapadnoe 
tailings of $180 \mathrm{TBq}$ presented in [7]. (The estimate in [7] was based on a relatively few activity measurements and therefore likely used higher end values for inventory calculations, which resulted in a biased inventory estimate).

\section{Cross-correlations of radionuclides}

Pearson product-moment correlation coefficients (correlation coefficients) [8] for all possible pairs of log-transformed radioactivityl parameters are summarized in Table 3. Table shows statistically significant correlations $(p<0.001)$ between gamma exposure rate (GER) and the following radionuclides: ${ }^{230} \mathrm{Th},{ }^{226} \mathrm{Ra}$ and ${ }^{210} \mathrm{~Pb}$, as well as in between the mentioned radionuclides.

\section{Table 3. Cross-correlation coefficients for logarithm-transformed values of radionuclide activity} of waste material in Zapadnoe tailings

\begin{tabular}{|c|c|c|c|c|c|}
\hline & $\ln (\mathrm{Pb}-210)$ & $\ln (\mathrm{Ra}-226)$ & $\ln (\mathrm{Th}-230)$ & $\ln (\mathrm{U}-238)$ & $\ln$ (ExpRate) \\
\hline $\ln (\mathrm{Pb}-210)$ & 1 & $0.95[\mathrm{DB} 1]^{*}$ & 0.87 & 0.36 & 0.64 \\
\hline $\ln (\mathrm{Ra}-226)$ & & 1 & 0.86 & 0.43 & 0.61 \\
\hline $\ln (\mathrm{Th}-230)$ & & & 1 & 0.32 & 0.67 \\
\hline $\ln (\mathrm{U}-238)$ & & & & 1 & 0.38 \\
\hline $\ln ($ ExpRate) & & & & & 1 \\
\hline
\end{tabular}

* Italic correlation coefficient values indicate statistically significant correlation at level $p=0.001$.

On the contrary, we see relatively low (and statistically insignificant) correlation between the gamma exposure rate and uranium, as well as between the uranium and other radionuclides of the uranium decay series. This can be explained by significant redistribution of uranium in the dissolved form in the residues due to water infiltration through the body of tailings following the disposal of wastes, while other radionuclides were relatively immobile in waste material.

\section{Geostatistical analysis}

The objective was to develop a structural model of radioactivity distribution in tailings in $3 \mathrm{D}$, and to estimate using kriging interpolation values of activity in nodes of a regular grid in a 3D space. The methodology developed previously by authors for the Chernobyl radioactive waste dumps was used [11]. The GSLIB geostatistical library was used as a software tool [12].

The first step of geostatistical analysis consisted in analysis of the spatial dependence and spatial correlation structure of the variables of interest. Spatial dependence was quantified and modeled using the semivariogram function [9 - 13]. Estimation of semivariogram (variogram) of the analyzed spatially distributed variable is a pre-requisite for a kriging interpolation, because the correlation matrix to obtain the kriging weight coefficients is constructed from variogram values. The variogram affects also the computation of kriging variance [8].

Variograms for the logarithm transformed radioactivity variables $(F)$ were calculated using the wellknown equation $[12,13]$

$$
\gamma(h)=\frac{1}{2 N(h)} \sum_{i=1}^{N(h)}\left(F_{i}-F_{i+h}\right)^{2}
$$

where $h$ is the separation distance between locations $x_{i}$ and $x_{i+h}$ in 3D space, $F_{i}$ and $F_{i+h}$ are the measured values of the analyzed variable at these locations, and $N(h)$ is number of pairs at a given separation distance $h$. Preliminary analyses have shown, that the radioactivity data set for Zapadnoe tailings was characterized by spatial anisotropy of correlation patterns. Therefore, computations of experimental variograms were carried out in two directions aligned with the tailings geometry: (1) X-Y plane, and (2) $\mathrm{Z}$ axis.

Geostatistical analyzes were carried out for two logarithm-transformed variables: (1) gamma exposure rate, and (2) uranium-238 content in wastes. As established above (see Table 3), there are high correlation coefficients between the GER and ${ }^{230} \mathrm{Th},{ }^{226} \mathrm{Ra}$ and ${ }^{210} \mathrm{~Pb}$ activity in the waste. Therefore spatial distribution of GER can be used in first instance to assess (and/or quantitatively estimate using correlation ratios) ${ }^{230} \mathrm{Th},{ }^{226} \mathrm{Ra}$ and ${ }^{210} \mathrm{~Pb}$ distribution in the tailings in $3 \mathrm{D}$.

The directional variograms for log-transformed GER data are shown at Fig. 3. These variograms demonstrate essentially anisotropy of the data set. The range (correlation length) for $\mathrm{Z}$ (vertical) direction is approximately $6 \mathrm{~m}$ (Fig. 4,a). For the $\mathrm{X}-\mathrm{Y}$ plane (along and across the tailings) the range is much larger reaching $\approx 90 \mathrm{~m}$ (see Fig. $4, b$ ).

Such spatial correlation patterns of radioactivity may be related to the technological methods of disposal of a pulp material to the containment dykes using slurry discharge pipeline. The spigot of the pipeline was periodically moved along the containment dike. The deposit cone of tailings material formed by slurry discharge was formed at each spigot position. The correlation scales can be related to characteristics dimensions (horizontal, vertical) of such deposit cones. 


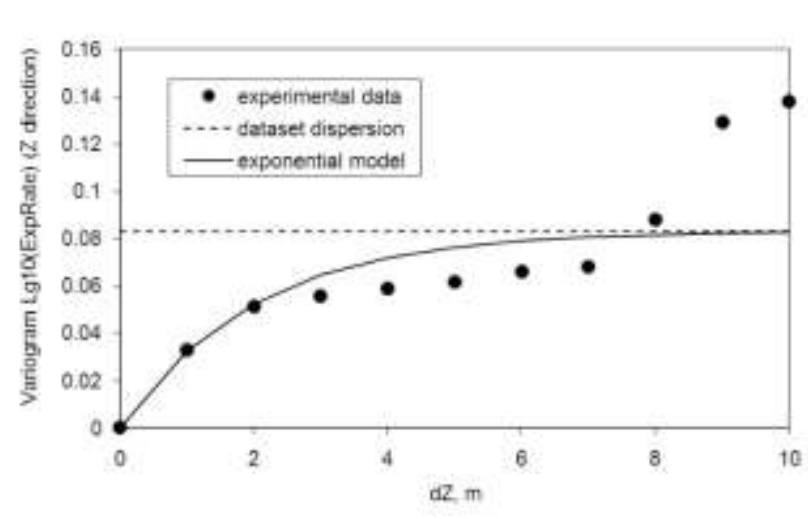

$a$

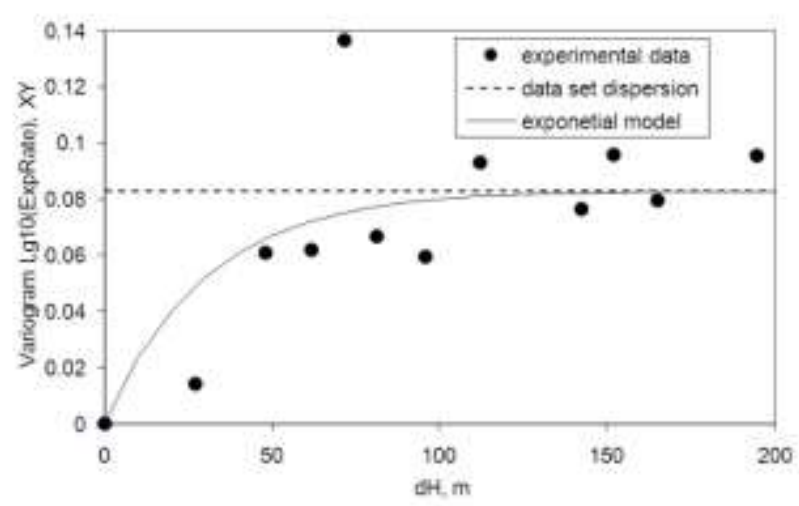

$b$

Fig. 4. Experimental variograms for logarithm-transformed gamma exposure rate data set for Zapadnoe tailings: Z direction $(a)$; X-Y plane $(b)$.

The spatial structure of the data set was approximated by the model exponential variograms (see Fig. 4). The equation for the exponential variogram is written as [12]

$$
\gamma(h)=c \operatorname{Exp}\left(\frac{h}{a}\right)=c\left[1-\operatorname{Exp}\left(-\frac{3 h}{a}\right)\right],
$$

where $a$ is a range, and $c$ is a sill. Fitted parameters are listed in Table 3.

The directional variograms for log-transformed uranium-238 data set are shown at Fig. 5. In the case of uranium we have smaller amount of sampling data points compared to GER data. This results in much less smooth variogarms (due to smaller number of data pairs).

The correlation range for $\mathrm{Z}$ axis (vertical direction) can be estimated at $4-5 \mathrm{~m}$ (see Fig. 5, a). The range for $\mathrm{X}-\mathrm{Y}$ plane is less than $12 \mathrm{~m}$, as varioagram value for this separation distance is already close to sill (data set variance) (see Fig. 5, b). This picture is quite different to that one observed for the GER parameter, where variables were correlated at significant distances in horizontal plane (see above). One of possible explanations for such a difference in spatial correlation patterns for uranium can be higher mobility of uranium, and its redistribution in waste material following the initial disposal to the tailings. Fitted parameters of the corresponding exponential model variogram are listed in Table 4.

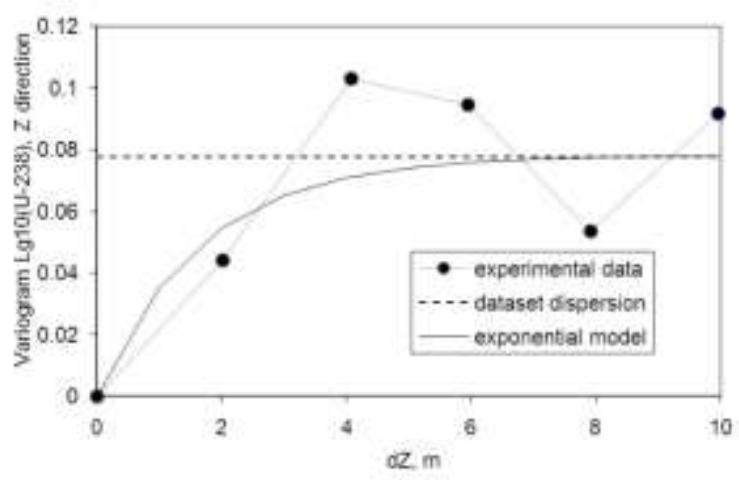

$a$

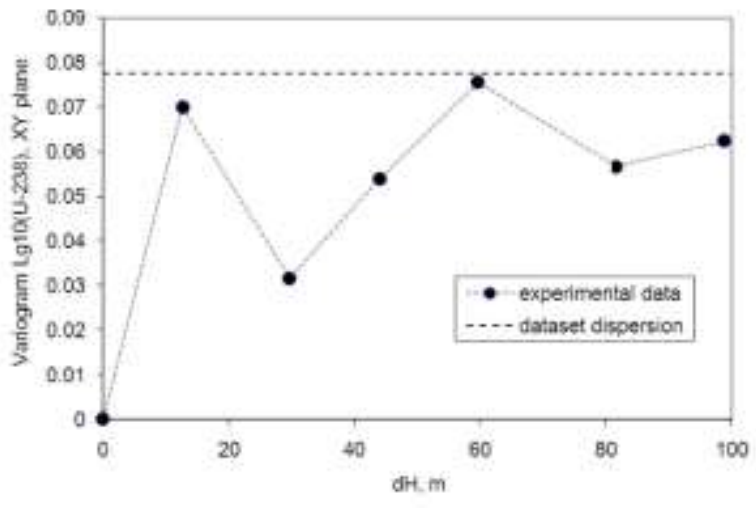

$b$

Fig. 5. Experimental variograms for logarithm-transformed uranium-238 activity data set for Zapadnoe tailings: $\mathrm{Z}$ direction $(a)$; $\mathrm{X}-\mathrm{Y}$ plane $(b)$.

\section{Table 4. Parameters of the exponential variogram models for radioactivity parameters in Zapadnoe tailings}

\begin{tabular}{|l|c|c|}
\hline $\begin{array}{l}\text { Variogram } \\
\text { parameter }\end{array}$ & Z axis & X-Y plane \\
\hline \multicolumn{2}{|c|}{ Gamma dose rate (logarithm-transformed) } \\
\hline Range $(a), \mathrm{m}$ & 6 & 90 \\
\hline Sill $(c)$ & 0.083 & 0.083 \\
\hline \multicolumn{2}{|c|}{ Uranium-238 (logarithm-transformed) } \\
\hline Range $(a), \mathrm{m}$ & 5 & $<12$ \\
\hline Sill $(c)$ & 0.078 & 0.078 \\
\hline
\end{tabular}

The developed structural models were used to assess distribution of radioactivity in Zapadnoe Tailings in 3D. The interpolation was carried out by ordinary kriging method by means of KT3D program from GSLIB library [12]. Calculation utilized variogram parameters listed in Table 4. The 3D interpolation grid had following dimensions: $\mathrm{N}_{\mathrm{x}}=23, \mathrm{~h}_{\mathrm{x}}=$ $=10 \mathrm{~m} ; \mathrm{N}_{\mathrm{y}}=11, \mathrm{~h}_{\mathrm{y}}=10 \mathrm{~m} ; \mathrm{N}_{\mathrm{z}}=11, \mathrm{~h}_{\mathrm{z}}=2 \mathrm{~m}$. The resulting grided values of interpolated variables were back transformed (using power transformation) to original radioactivity parameters. 
An example visualization of uranium distribution in Zapadnoe tailings is shown at Fig. 6. It clearly shows highly heterogeneous distribution of uranium activity inside the tailing impoundments. We can observe that upper and middle zones of the tailings tend to contain noticeably higher contents in uranium compared to lower layers.

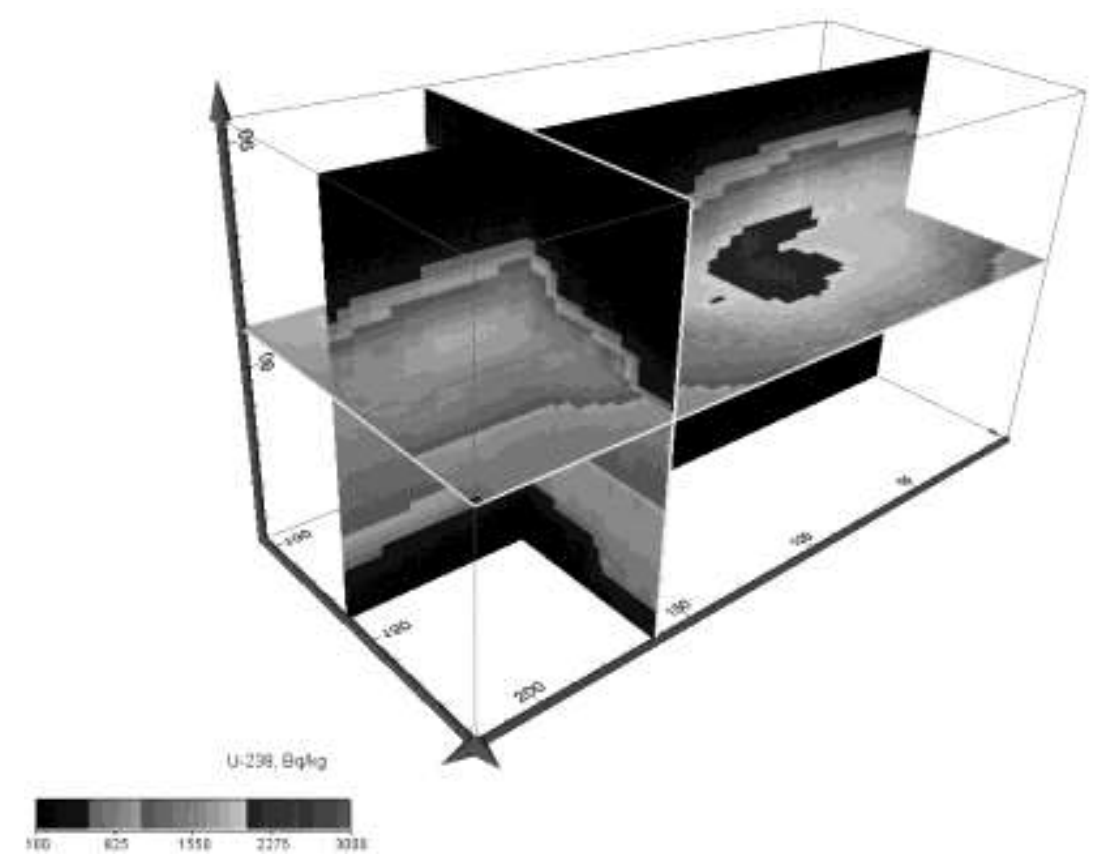

Fig. 6. Distribution of uranium-238 inside the tailings:

3 D visualization of interpolated values using vertical and horizontal "slices".

\section{Conclusions}

Presented above results of comprehensive field characterization works, analytical works and rigorous calculations using statistical methods allowed essentially refining the waste volume $\left(253400 \mathrm{~m}^{3}\right)$ and radioactivity inventory of long-lived radionuclides $(14.1 \pm 1.4 \mathrm{TBq})$ estimates for Zapadnoe tailings impoundment compared to earlier estimates (350000 $\mathrm{m}^{3}$ and $180 \mathrm{TBq}$ respectively).

It was established also that spatial radioactivity distribution in Zapadnoe tailings was characterized by regular spatial correlation patterns. The logtransformed gamma exposure rate data set was found to be essentially anisotropic. The range (correlation length) for $\mathrm{Z}$ (vertical) direction is approximately 6 $\mathrm{m}$. For the X-Y plane (along and across the tailings) the range is much larger reaching $\approx 90 \mathrm{~m}$. Such spatial correlation patterns of radioactivity may be related to the technological methods of disposal of tailings material to the containment dykes using slurry discharge pipeline (as discussed above in the article). It should be noted that there are high correlation coefficients between the GER and ${ }^{230} \mathrm{Th},{ }^{226} \mathrm{Ra}$ and ${ }^{210} \mathrm{~Pb}$ activity in the waste. Therefore, spatial distribution of GER can be used in first instance to analyze, visualize, or estimate using correlation ratios ${ }^{230} \mathrm{Th},{ }^{226} \mathrm{Ra}$ and ${ }^{210} \mathrm{~Pb}$ distribution in the tailings in 3D.
The picture of spatial correlation for the uranium238 was quite different. The range for X-Y plane was less than $12 \mathrm{~m}$. The correlation range for $\mathrm{Z}$ axis (vertical direction) was estimated at $4-5 \mathrm{~m}$. One of possible explanations for such a difference in spatial correlation patterns for uranium and GER parameters can be higher mobility of uranium compared to other gamma-emitting radionuclides (such as ${ }^{226} \mathrm{Ra}$ and ${ }^{230} \mathrm{Th}$ ), and its redistribution in waste material with water fluxes following the initial disposal to the tailings. Such an explanation is consistent with the uranium plume in groundwater observed downstream from the tailings. [3].

The established parameters of spatial dependence and correlation of radioactivity distribution in $\mathrm{Za}-$ padnoe tailings also represent practical interest from the view point of optimizing sample collection procedures when characterizing other similar uranium mill tailings at the PChP Site. The rule of thumb principle is that sample collection (borehole drilling and core sampling) spacing should be less than half of the range for the variogram [13]. The derived radioactivity inventory estimates can be used also to assess feasibility of reprocessing of tailings materials for secondary extraction of uranium.

The reported results are obtained in the frame of international technical assistance project ENSURE-II funded by Swedish SIDA and managed by SSM (Swedish Radiation Safety authority). 


\section{REFERENCES}

1. Lavrova T., Voitsekhovych O. Radioecological assessment and remediation planning at the former uranium milling facilities at the Pridneprovsky Chemical plant in Ukraine // J. Env. Radioactivity. - 2013. - Vol. 115. P. $118-123$.

2. Skalskyy O., Bugai D., Voitsekhovitch O. et al. Groundwater monitoring data and screening radionuclide transport modeling analyses for the uranium mill tailings at the Pridneprovsky Chemical Plant Site (Dneprodzerginsk, Ukraine) // The New Uranium Mining Boom: Challenge and lessons learned / Eds. B. Merkel, M. Schipek. - Berlin: Springer - Verlag, 2011. - P. 219 - 228.

3. Bugai D., Kozak M.W., Van Blerk J.J., Avila R. Radiological Safety Assessment of the Zapadnoe Uranium Tailings Facility, Dnieprodzerzhinsk, Ukraine // Proc. of EU NORM 2 Symposium (Prague, 17 - 19 June, 2014). DOI: $10.13140 / 2.1 .1575 .5527$.

4. Protsak V.P., Kashparov V.O., Kyrychenko V.K. et al. // Nucl. Phys. At. Energy. - 2013. - Vol. 14, No. 1. - P. 55 - 63. (Ukr)

5. De Corte F., Umans H., Vandenberghe D. et al. Direct gamma-spectrometric measurement of the ${ }^{226} \mathrm{Ra}$ $186.2 \mathrm{keV}$ line for detecting ${ }^{238} \mathrm{U} /{ }^{226} \mathrm{Ra}$ disequilibrium in determining the environmental dose rate for the luminescence dating of sediments // Appl. Radiat. Isot. 2005. - Vol. 63, No. 5. - P. 589 - 598.

6. Appleby P.G., Richardson N., Nolan P.J. Selfabsorption corrections for well-type germanium detectors // Nucl. Instr. Meth. Phys. Res. B. - 1992. Vol. 71, No. 2. - P. 228 - 233.
7. Research and development of radioactive waste storage technology at the State Enterprise "Barrier". Analysis of the operations safety for the radioactive waste storage. Tailings "Zapadnoe". Assessment of the radioactive waste storage conditions: Report of the Ukrainian Scientific Research and Design Institute of Industrial Technologies. 2001 / Ministry of Fuel and Energy of Ukraine. - State registration No. A-15969. Agreement 3032. - 38 p. (Rus)

8. Walpole R.E., Myers R.H., Myers S.L., Ye K. Probability and statistics for engineers and scientists. - London: Pearson Prentice Hall, 2007. - 490 p.

9. Kitanidis $P$. Geostatistics: Interpolation and inverse problems // The handbook of groundwater engineering / Ed. J. W. Delleur. - CRC Press, Boca Raton, 1999. P. 12-1 - 12-20.

10. Practical aspects of applying geostatistics at hazardous, toxic, and radioactive waste sites: U. S. Army Corps of Engineers. Technical letter-report no. 1110-1-175. - Washington D.C., 1997. - 125 p.

11. Bugai D., Kashparov V., Dewiére L. et al. Characterization of subsurface geometry and radioactivity distribution in the trench containing Chernobyl clean-up wastes // Environ. Geol. - 2005. - Vol. 47. - P. 869 - 881.

12. Deutch C.V., Journel A.J. GSLIB. Geostatistical software library and user's guide. - New York - Oxford: Oxford University Press, 1998. - 369 p.

13. Mulla D.J., McBratney A.B. Soil spatial variability // Handbook of soil science / Ed. M. E. Sumner. - CRC Press, Boca Raton, 2000. - P.A-321 - A-352.

\section{Д. О. Бугай ${ }^{1}$, Г. В. Лаптєв², О. С. Скальский ${ }^{1}$, Т. В. Лаврова ${ }^{2}$, Р. Авіла ${ }^{3}$ \\ ${ }^{1}$ Інститут геологічних наук НАН України, Київ \\ ${ }^{2}$ Украӥнський гідрометеорологічний інститут НАН та ДСНС України, Київ \\ ${ }^{3}$ Фасілія АБ, Бромма, Швеиія}

\section{АНАЛІЗ ПРОСТОРОВОГО РОЗПОДІЛУ І ЗАПАСІВ АКТИВНОСТІ В УРАНОВОМУ ХВОСТОСХОВИЩІ}

Представлено результати по характеристиці запасів радіоактивності у хвостосховищі відходів переробки уранових руд «Західне», що знаходиться на проммайданчику Придніпровського хімічного заводу (ПХЗ) (Дніпродзержинськ, Україна). Проаналізований набір даних, який було отримано на основі аналітичних досліджень кернового матеріалу з 15 свердловин, дав змогу суттєво уточнити об'єм і запаси активності у відходах. Геостатистичний аналіз із використанням варіограмм установив, що розподіл радіоактивності у хвостосховищі характеризується регулярними просторовими кореляційними залежностями. Для оцінювання просторового розподілу радіоактивності у трьох вимірюваннях було використано крайгінг-інтерполяцію. Результати статистичного аналізу вказують на суттєвий перерозподіл урану в розчиненому вигляді у відходах. Розроблена структурна модель для розподілу радіоактивності в подальшому буде використана для оцінок ризиків. Отримані параметри просторової кореляції можуть бути використані для оптимізації відбору проб при характеристиці ПХ3, а також для інших аналогічних забруднених об'єктів.

Ключові слова: уранове хвостосховище, Придніпровський хімічний завод, оцінка запасів радіоактивності, геостатистичний аналіз. 


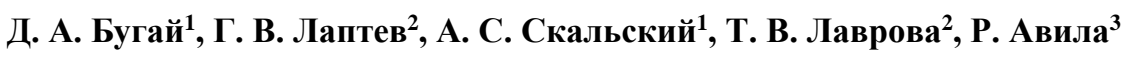

${ }^{1}$ Институт геологических наук НАН Украины, Киев

${ }^{2}$ Украинский гидрометеорологический институт НАН и ГСЧС Украины, Киев

${ }^{3}$ Фасилия АБ, Бромма, Швеция

\section{АНАЛИЗ ПРОСТРАНСТВЕННОГО РАСПРЕДЕЛЕНИЯ И ЗАПАСОВ АКТИВНОСТИ В УРАНОВОМ ХВОСТОХРАНИЛИЩЕ}

Представлены результаты по характеристике запасов радиоактивности в хвостохранилище отходов переработки урановых руд «Западное», которое расположено на промплощадке Приднепровского химического завода (ПХЗ) (Днепродзержинск, Украина). Проанализированный набор данных, полученный на основе аналитических исследований кернового материала из 15 скважин, позволил существенно уточнить объем и запасы активности в отходах. Геостатистический анализ с использованием вариограмм установил, что распределение радиоактивности в хвостохранилище характеризуется регулярными пространственными корреляционными зависимостями. Для оценивания пространственного распределения радиоактивности в трех измерениях была использована крайгинг-интерполяция. Результаты статистического анализа указывают на существенное перераспределение урана в растворенном виде в отходах. Разработанная структурная модель для распределения радиоактивности в дальнейшем будет использована для оценок рисков. Полученные параметры пространственной корреляции могут быть использованы для оптимизации отбора проб при характеристике ПХЗ, а также для других аналогичных загрязненных объектов.

Ключевые слова: урановое хвостохранилище, Приднепровский химический завод, оценка запасов радиоактивности, геостатистический анализ. 